\title{
PANDANGAN NASIONALISME DALAM PUISI MAHMUŪD DARWISY DAN RENDRA DALAM ANALISIS SASTRA BANDING
}

\author{
Nationalism View to Mậmūd Darwisy and Rendra poetries \\ in Comparative Literature analysis \\ Evayatun Ni'mah \\ Universitas Gajah Mada Yogyakarta \\ evaenimah@gmail.com
}

\begin{abstract}
Abstrak :
"Penelitian ini bertujuan untuk mengetahui tentang pandangan nasionalisme dalam dua puisi yang berbeda, yaitu puisi Arab dan Puisi Indonesia. Hal yang dibandingkan dari dua puisi tersebut adalah pandangan tentang negara dan perjuangan melawan penjajah. Penelitian ini menggunakan teori sastra banding, yaitu membandingkan karya sastra dari dua negara yang berbeda, bahasa yang berbeda, dan juga budaya yang berbeda. Penelitian ini menghasilkan adanya perbedaan dan persamaan antara dua karya sastra berbentuk puisi dari dua negara, yaitu Arab dan Indonesia. Puisi Arab "Bitāqah Hāwiyyah" karya Darwisy merepresentasikan bahwa negara adalah rumah bagi rakyat Palestina. Adapun puisi "Gugur" karya Rendra menggambarkan bahwa negara itu adalah jiwa bagi para penduduk Indonesia. Kedua puisi tersebut memiliki perspektif yang berbeda dalam memandang suatu negara. Akan tetapi, kedua puisi tersebut memiliki wujud rasa nasionalisme yang sama, yaitu sebuah perjuangan melawan penjahahan."
\end{abstract}

Kata kunci: nasionalisme, negara, perjuangan, penjajah.

\section{PENDAHULUAN}

Nasionalisme berasal dari kata nation yang berarti bangsa. Secara bahasa, istilah nasionalisme berasal dari kata natio dalam bahasa latin dan bermakna bangsa yang dipersatukan karena kelahiran. Kata natio tersebut berasal dari kata nascie yang berarti dilahirkan. ${ }^{1}$ Menurut Hans Kohn, nasionalisme adalah suatu paham yang berpendapat bahwa kesetiaan tertinggi individu harus diserahkan kepada negara kebangsaan. Paham tersebut mulai muncul ketika suatu bangsa memiliki cita-cita yang sama untuk membangun suatu negara. ${ }^{2}$

\footnotetext{
${ }^{1}$ Moesa, Ali Maschan, Nasionalisme Kiai (Yogyakarta: Lkis, 2007), 28.

${ }^{2}$ Kohn, Hans, Nasionalisme: Arti dan Sejarahnya (Jakarta : Penerbit Erlangga, 1985), 11.
} 
Evayatun Ni'mah

Kata 'nasionalisme' menurut Abbe Barruel untuk pertama kalinya dipakai di Jerman pada abad ke-15. Kata tersebut diperuntukkan bagi para mahasiswa yang datang dari daerah yang sama atau berbahasa sama, sehingga mereka tetap menunjukkan cinta mereka terhadap bangsa atau suku asal mereka meskipun mereka berada di tempat yang baru. ${ }^{3}$ Nasionalisme pada mulanya terkait dengan rasa cinta sekelompok orang pada bangsa, bahasa, dan daerah asal usul semula. Rasa cinta seperti itu dewasa ini disebut semangat patriotisme. Jadi pada mulanya nasionalisme dan patriotisme itu sama maknanya.

Snyder ${ }^{4}$ beranggapan bahwa nasionalisme sebagai satu emosi yang kuat yang telah mendominasi pikiran dan tindakan politik kebanyakan rakyat sejak revolusi Perancis. Ia tidak bersifat alamiah, melainkan merupakan satu gejala sejarah, yang timbul sebagai tanggapan terhadap kondisi politik, ekonomi dan sosial tertentu. Sebagai ideologi, nasionalisme dapat memainkan tiga fungsi, yaitu mengikat semua kelas warga bangsa, menyatukan mentalitas warga bangsa, dan membangun atau memperkokoh pengaruh warga bangsa terhadap kebijakan yang diambil oleh negara. Nasionalisme merupakan salah satu alat perekat kohesi sosial untuk mempertahankan eksistensi negara dan bangsa.

Namun sejak revolusi Perancis meletus 1789, pengertian nasionalisme mengalami berbagai pengertian, sebab kondisi yang melatarbelakanginya amat beragam antara bangsa yang satu dengan bangsa yang lain. Nasionalisme bukan lagi produk pencerahan Eropa tetapi menjadi label perjuangan di negara-negara Asia-Afrika yang dijajah oleh bangsa Barat. Shafer ${ }^{5}$ mengatakan bahwa nasionalisme itu multi makna. Hal tersebut tergantung pada kondisi objektif dan subjektif dari setiap bangsa. Karena kendatinya negara-negara Eropa dan Asia-Afrika memiliki perbedaan peradaban, kebudayaan, bahkan ras, maka label nasionalisme dalam dua kubu tersebut juga berbeda.

Ketika melihat negara-negara Asia Afrika, tentu selalu ingat akan adanya panArabisme atau pan-Islamisme yang sampai saat ini bertujuan untuk menyatukan negaranegara Timur Tengah. Jika melihat keadaan geografis dan politik di Timur Tengah, maka dapat dikatakan bahwa Timur Tengah terdiri dari banyak negara yang memiliki suku, bahasa, agama, dan kebudayaan yang hampir sama. Sebelum adanya pengaruh-pengaruh

\footnotetext{
${ }^{3}$ Ritter, Herry, Dictionary of Concepts in History (New York: Greenwood Press, 1986), 295.

${ }^{4}$ Snyder, L. L, The Dynamic of Nationalism (Princeton: D. Van Nostrand Co. Inc, 1964), 23.

5 Shafer, Boyd C, Nationalism Myth and Reality (New York: A Harvest Book Harcourt, 1955), 6.
} 
politik dari Barat, negara-negara di Timur tengah telah disatukan oleh ikatan keagaman dan kesukuan. Akan tetapi, adanya modernisasi di dunia Arab merupakan cikal bakal timbulnya kebangkitan politik bangsa Arab. Salah satu paham yang dihasilkan dari dampak modernisasi politik di Timur Tengah adalah nasionalisme Arab. Dalam perkembangan modernitasnya, nasionalisme Arab sepenuhnya muncul karena keadaan politik yang dihadapi dunia Arab saat itu. Nasionalisme Arab baru benar-benar muncul ke permukaan ketika ada tekanan politik dari luar yang memaksa kaum nasionalis Arab berbuat sesuatu. Persatuan Arab atau yang disebut dengan Pan Arabisme merupakan wujud dari cita-cita nasionalisme Arab.

Pada dasarnya, nasionalisme Arab bertujuan untuk mempersatukan negara-negara berbahasa Arab yang memiliki kesamaan dalam hal suku dan kabudayaan, bukan persatuan dunia Islam. Hal ini menunjukkan bahwa negara-negara Arab merupakan satu bangsa dan satu budaya, apapun agama yang ada di dalamnya.

Apa yang terjadi di negara-negara Arab berbeda dengan negara Indonesia. Nasionalisme di Indonesia muncul ketika kolonialisme merajalela dalam bentuk keserakahan, ketidakadilan, kebengisan, diskriminasi, dan penafian atas hak asasi manusia. Bentuk nasionalisme di Indonesia adalah anti terhadap kolonialisme, artinya nasionalisme dibangun untuk mewujudkan bagaimana bangsa ini merdeka dan bebas dari belenggu kolonialisme. Jadi, telah terbukti bahwa nasionalisme Indonesia yang kemudian terwujud dalam Pancasila adalah alat yang ampuh untuk mengusir penjajah atau kolonialisme.

Di negeri-negeri Asia pada zaman modern, nasionalisme merupakan hasil yang paling penting dari pengaruh kekuasaan Barat. Tentu saja nasionalisme di negeri-negeri Asia dan khususnya di Indonesia tidak dapat disamakan dengan di Barat, karena ia merupakan suatu gejala historis yang telah berkembangan sebagai jawaban terhadap kondisi politik, ekonomi, dan sosial khususnya yang ditimbulkan oleh situasi kolonial. Hal yang esensial bahwa nasionalisme dan kolonialisme itu tidak terlepas satu sama lain, dan terasa juga adanya pengaruh timbal balik antara nasionalisme yang sedang berkembang dan politik kolonial dengan idiologinya, yang menganggap bahwa peradaban Barat itu lebih tinggi dan berbeda sama sekali dengan kebudayaan Timur. ${ }^{6}$

Nasionalisme Indonesia, tidak bisa disamakan dengan nasionalisme Barat karena nasionalisme Indonesia adalah nasionalisme yang bersenyawa dengan keadilan sosial,

\footnotetext{
${ }^{6}$ Kartodirdjo, Sartono, Pengantar Sejarah Indonesia Baru: Sejarah Pergerakan Nasional dari Kolonialisme Sampai Nasionalisme, Jilid 2 (Jakarta: Gramedia, 1999), 58.
} 
anti kolonialisme yang oleh Bung Karno disebut socio-nasionalism. Nasionalisme yang demikian adalah nasionalisme yang menghendaki penghargaan, penghormatan, toleransi kepada bangsa atau suku-bangsa lain. Dalam konteks Indonesia, pengalaman penderitaan bersama sebagai kaum terjajah melahirkan semangat solidaritas sebagai satu komunitas yang mesti bangkit dan hidup menjadi bangsa merdeka. Semangat tersebut oleh para pejuang kemerdekaan dihidupkan tidak hanya dalam batas waktu tertentu, tetapi terusmenerus hingga kini dan masa mendatang.

Selanjutnya, nasionalisme Indonesia melahirkan Pancasila sebagai ideologi negara. Perjuangan yang lama untuk mencapai kemerdekaan kini telah terwujud. Proklamasi Kemerdekaan 17 Agustus 1945 adalah sebagai puncak perjuangan, dan sekaligus pertanda bahwa Indonesia menyatakan sebagai negara yang berdaulat, merdeka, dan mandiri. Untuk memperkuat itu semua, disahkanlah Undang-Undang Dasar 1945 pada tanggal 18 Agustus, yang menjadi simbol kekuasaan besar yang revolusioner yang mengandung persamaan dan persaudaraan, suatu tanda hari cerah setelah digulingkannya kekuasaan asing ${ }^{7}$.

Rasa cinta terhadap tanah air merupakan bentuk dari nasionalisme. Meskipun setiap generasi memiliki tantangan dan jawaban tersendiri mengenai perwujudan nasionalisme, namun esensi nasionalisme tetap sama, yaitu adanya keterikatan diri terhadap negara dan tanah air. Topik mengenai nasionalisme tidak hanya diangkat dalam tulisan-tulisan ilmiah, tetapi dapat juga diangkat ke dalam bentuk karya sastra. Karya sastra merupakan sebuah hasil ciptaan dan kreasi yang diimajinasikan oleh manusia dan merupakan cerminan kehidupan sosial dan budaya masyarakat. Karya sastra dengan jelas merefleksikan norma dan perilaku masyarakat dalam berbagai macam kelas sosial. ${ }^{8}$

Pengarang biasanya merefleksikan kehidupan nyata ke dalam karya sastra dengan tujuan untuk menyampaikan pesan. Banyak pengarang yang mengungkapkan fenomena sosial, khususnya mengenai nasionalisme, apa dan bagaimana perspektifnya ke dalam karya sastra. Oleh karena itu, makalah ini membedah konsep nasionalisme dari dua karya sastra Arab dan Indonesia sekaligus, yaitu pada puisi Arab "Bitāqah Hāwiyyah" karya Mahmūd Darwisy dan puisi Indonesia "Gugur" karya W.S. Rendra.

Kedua pengarang tersebut memiliki pandangan yang berbeda dalam memaknai rasa nasionalisme. Hal itu disebabkan karena keduanya memiliki latar belakang sejarah

\footnotetext{
7 Kahin, George Mc Turnan, Nasionalisme dan Revolusi di Indonesia, (Jakarta: Sinar Harapan, 1995), 175.

${ }^{8}$ Laurenson, Diana dan Alan Swingewood, Sociology of Literature (London: Granada Publishing Limited, 1972), 15.
} 
dan sosial yang berbeda. Darwisy yang lahir di Palestina memiliki pengalaman yang cukup menyakitkan mengenai pendudukan dan pembersihan etnik Palestina yang dilakukan oleh Israel terhadap tanah airnya dan dia harus merasakan kehilangan yang mendalam akan negaranya, Palestina. Adapun Rendra memiliki pengalaman dengan kondisi Indonesia yang dijajah oleh Belanda dan Jepang, namun Indonesia berhasil mendapatkan kemerdekaannya dengan segala perjuangan rakyat Indonesia dan rasa nasionalisme yang tinggi.

Dua karya sastra dari negara yang berbeda tersebut akan mewakili penggambaran perbandingan makna nasionalisme dan konsepnya. Penelitian ini mengangkat tema tentang perbandingan antara konsep nasionalisme puisi Arab dan puisi Indonesia. Dalam membandingkan kedua karya sastra tersebut, digunakanlah teori sastra banding untuk membedah perbedaan konsep nasionalisme.

Sastra banding adalah teori sastra yang melampaui batasan-batasan pada satu negara tertentu dan juga merupakan studi atas hubungan antara sastra itu sendiri dengan bidang ilmu lainnya, seperti seni, filosofi, sejarah, ilmu-ilmu sosial, dan juga agama. Dengan kata lain, pengaplikasian teori ini adalah membandingkan antara karya sastra dengan karya sastra lain ataupun dengan bidang lain, seperti yang telah dijelaskan di atas. ${ }^{9}$ Webster menjelaskan bahwa perbandingan dipelajari secara sistematis dengan membandingkan fenomena, seperti sastra banding, yaitu membandingkan fenomena yang ada dalam karya sastra. ${ }^{1}$

\section{Metode Penelitian}

Penelitian ini menggunakan metode kualitatif, tepatnya metode deskriptif kualitatif. Metode ini digunakan sebagai cara menguraikan masalah dengan menggambarkan keadaan objek penelitian berupa dua puisi dari Darwisy dan Rendra berdasar pada fakta yang tampak di dalamnya. Metode penelitian ini meliputi metode pengumpulan data, analisis data, dan penyimpulan data. Dalam tahap pengumpulan data, kedua puisi tersebut memuat fakta sastra yang lengkap mengenai makna nasionalisme antara keduanya. Dalam metode analisis data, kedua puisi tersebut dicari makna-makna yang terkandung di dalamnya dan diambil kesimpulan mengenai pandangan

\footnotetext{
${ }^{9}$ Newton P. Stallknect dan Horst Frenz (Ed), Comparative Literature: Method and Perspective (Carbondale: Southern Illinois University Press), 3.

1 Newton P. Stallknect dan Horst Frenz (Ed), Comparative Literature: Method and Perspective

(Carbondale: Southern Illinois University Press), 14.
} 
Evayatun Ni'mah

nasionalisme. Kemudian tahap terakhir adalah penyimpulan yang memuat tentang kesimpulan akhir dari perbandingan makna nasionalisme atau pandangan nasionalisme kedua puisi tersebut dari pengarang yang berbeda dan dari negara yang berbeda.

\section{Analisis Penelitian: Pandangan Nasionalisme antara Puisi Darwisy dan Rendra}

Tema perjuangan dan nasionalisme sama-sama diangkat ke dalam dua puisi yang berbeda, yaitu puisi Arab dan Indonesia. Namun, kedua puisi tersebut memiliki konsep perjuangan dan nasionalisme yang berbeda dikarenakan latar sosial dan budaya keduanya yang berbeda. Dalam puisi Arab "Bitāqah Hāwiyyah" yang dalam bahasa Inggris berarti "Identity Card" dan dalam bahasa Indonesia berarti "Kartu Identitas", nasionalisme dipandang sebagai sebuah cinta terhadap negaranya yang menjadi rumahnya. Adapun dalam puisi Indonesia "Gugur", negara dianggap sebagai jiwa yang kehormatannnya harus dijaga. Di samping perbedaan yang ada dalam kedua puisi tersebut, ada satu kesamaan dalam hal perjuangan pembebasan negara dari penjajah. Dari kedua puisi tersebut dapat terlihat bagaimana rakyat pribumi mempertahankan negaranya dari para penjajah.

\section{a. Puisi "Bitāqah Hāwiyyah" Karya Mạ̣mūd Darwisy}

Puisi tersebut merupakan puisi Palestina yang ditulis oleh Mahmūd Darwisy dan diterbitkan pada tahun 1964. Puisi itu bercerita tentang perjuangan rakyat Palestina melawan penjajahan Israel yang memporak-porandakan negara Palestina. Israel merebut semua yang ada di negara Palestina, tanahnya, kebun-kebunnya, pekerjaan rakyatnya, dan juga rumah-rumahnya. Perjuangan yang dilakukan merupakan salah satu bentuk rasa cinta terhadap tanah air. Kebanggaan Darwisy sebagai orang Arab Palestina menjadi sebuah kekuatan untuk menunjukkan bahwa dirinya merupakan bagian dari bangsa Arab yang besar. Hal itu ditunjukkan dengan penyebutannya yang berulang-ulang sebagai orang Arab dalam setiap bait puisi itu.

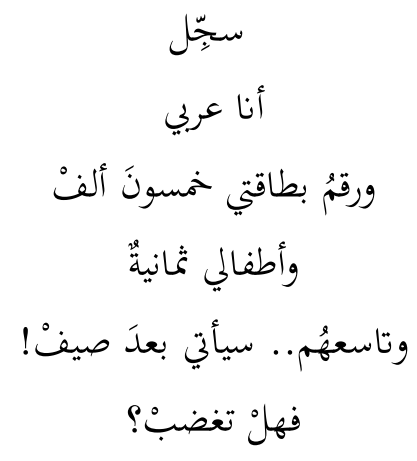

Volume 2, Nomor 1, Februari 201796 


\author{
'Catat! \\ Aku orang Arab \\ Dan nomor kartu identitasku lima puluh ribu \\ Aku punya delapan anak \\ Dan yang kesembilan, akan datang setelah musim panas! \\ Apakah engkau marah?'
}

Ia tidak menyebutkan secara jelas bahwa ia merupakan penduduk Palestina karena Palestina sendiri merupakan bagian dari dunia Arab. Ia merasa bangga dengan identitasnya menjadi orang Arab dengan menyebutkan nomor kartu identitasnya. Hal itu menegaskan bahwa ia benar-benar orang Arab dan namanya telah tercatat sebagai penduduk Arab Palestina. Dari hal itu, terlihat bahwa nasionalisme Arab dibangun untuk menyatukan negara-negara Arab, salah satunya adalah Palestina.

Bagi Darwisy, sebagai rakyat yang negaranya sedang dalam keadaan penjajahan, sebuah perjuangan dibutuhkan dalam mempertahankan negara dan segala sesuatu yang ada di dalamnya. Hal itu dikarenakan sebuah negara atau tanah air merupakan rumah bagi jutaan rakyatnya, seperti seorang ibu yang menjadi tempat berlindung bagi anaknya. Palestina merupakan tempat tinggal bagi Darwisy dan keluarganya. Negara Palestina bagi penduduknya juga merupakan sebuah tempat untuk bekerja dan menghidupi keluarganya. Lalu ketika negara itu dijajah dan direbut oleh Israel, bagaimana Darwisy dan penduduk Palestina lainnya akan hidup dan dimana mereka akan tinggal. Hal itu menjadi krusial karena segala kehidupan Darwisy dan penduduk Palestina lainnya tercurah di sana.

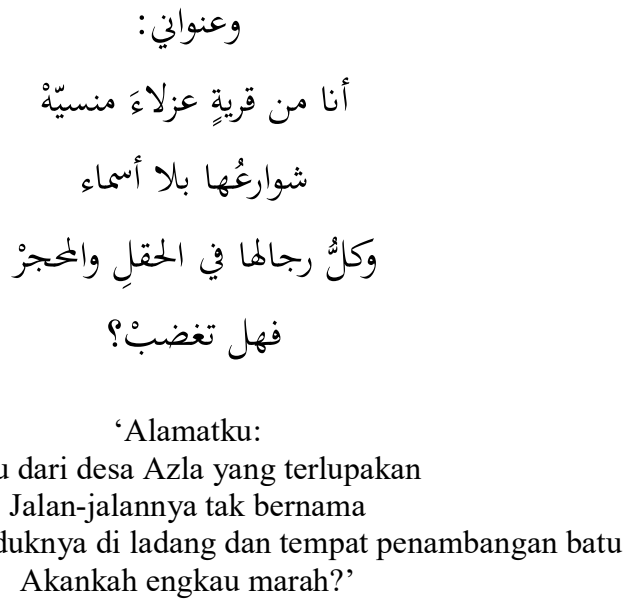

Negara sebagai rumah bukanlah berupa bentuk fisik rumah yang biasa ditempati oleh orang, tetapi rumah yang dimaksud adalah negaranya, tanah airnya. Dalam puisinya, ia banyak mengilustrasikan dan menggambarkan keadaan tanah airnya dan rasa tak terpisahkan dengan tanah airnya. Hal itu mejelaskan bahwa adanya kesatuan Darwisy dengan rumahnya, yaitu tanah airnya. Ia merasa bahwa rumahnya, tanah airnya memiliki 
Evayatun Ni'mah

ikatan yang kuat dengan penghuninya, yaitu rakyatnya (Ahmad, tt: 398-399). Karena baginya, negara Palestina adalah sebuah tempat ia dilahirkan, dibesarkan dan ditinggali. Palestina juga telah memberikan keluarganya tempat berlindung, tempatnya mendapatkan pekerjaan untuk menghidupi keluarganya, dan juga tempat di mana ia merasa nyaman.

Pada bait terakhir puisinya itu, ia menegaskan kembali bahwa dia benar-benar beridentitas Arab Palestina dan akan melakukan apapun demi mempertahankan tanah air tercintanya. Berikut petikan bait terakhir puisi tersebut:

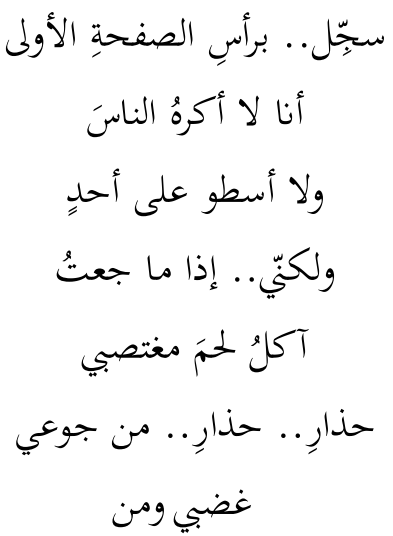

Catat!... di bagian atas halaman pertama:

Aku tak membenci orang-orang

Dan tak pula mengganggu seorang pun

Tapi... jika aku lapar

Aku akan makan daging para perampas

Hati-hati.. hati-hati...

dari kelaparanku

dan juga kemarahanku!!

Ia menunjukkan perlawanannya atas penderitaan yang selama ini ia rasakan dan juga atas penindasan yang dilakukan oleh penjajah. Ia memberikan peringatan yang keras bahwa jika penjajahan yang mengakibatkan kehidupannya penuh dengan penderitaan itu terus berlanjut, maka ia akan melakukan perlawanan terhadap penjajahan tersebut. Perlawanannya juga terlihat di baris pertama setiap baitnya, yaitu kata 'Catat!'. Ia ingin menunjukkan keberaniannya kepada penjajah. Pengulangan di setiap bait tersebut menunjukkan kekuatan dan keberaniannya bahwa ia benar-benar orang Arab yang tidak perlu pergi meninggalkan Palestina karena adanya penjajahan yang dilakukan oleh Israel.

Dari penjelasan di atas, dapat disimpulkan bahwa puisi Mahmūd Darwisy yang berjudul Bițāqah Hawiyyah memiliki tema perlawanan rakyat Palestina terhadap 
penjajahan Israel. Rakyat Palestina yang memiliki identitas Arab Palestina dan telah hidup beribu-ribu tahun di tanah Palestina harus merasakan penindasan yang dilakukan oleh Israel. Mereka harus kehilangan tempat tinggal dan kehidupannya karena telah dirampas oleh Israel.

\section{b. Puisi "Gugur" Karya Rendra}

Sama dengan puisi milik Darwisy, puisi "Gugur" menceritakan tentang perjuangan seseorang, sebagai perwakilan dari penduduk membela kemerdekaan di tanah Indonesia dimana ia berjuang melawan penjajah hingga tumpah darah untuk memperjuangkan tanah Ambarawa, salah satu kota di Indonesia. Hal itu patut diperjuangkan karena Ambarawa merupakan salah satu warisan leluhur yang subur dan harus diperjuangkan dan dilestarikan untuk generasi yang akan datang. Perjuangan penduduk Indonesia melawan penjajah sama dengan perjuangan rakyat Palestina melawan Israel dalam puisi Darwisy. Indonesia merupakan negara yang kaya akan sumbr daya alamnya. Dan karena hal itu, penjajah merampas segala hal yang ada di Indonesia. Namun, penduduk Indonesia juga tidak tinggal diam menghadapi serangan dari penjajah. Mereka juga melakukan perlawanan untuk mengusir penjajah dari negera tercintanya, seperti yang tercantum pada awal bait puisi Rendra berikut ini:

$$
\begin{gathered}
\text { Ia merangkak } \\
\text { di atas bumi yang dicintainya } \\
\text { Tiada kuasa lagi menegak } \\
\text { Telah ia lepaskan dengan gemilang } \\
\text { pelor terakhir dari bedilnya } \\
\text { Ke dada musuh yang merebut kotanya }
\end{gathered}
$$

Apa yang dilakukan oleh penduduk Indonesia merupakan suatu tindakan membela negara. Hal itu adalah sebagai dampak dari rasa cinta tanah air yang tinggi. Dan rasa cinta tanah air merupakan suatu akibat dari adanya rasa nasionalisme terhadap negara tercinta. Penduduk Indonesia memiliki satu tujuan yaitu kemerdekaan bangsa Indonesia. Pengalaman penderitaan yang telah lama hidup dalam kehidupvan penduduk Indonesia melahirkan semangat solidaritas dan rasa setia kepada negara.

Makna nasionalisme yang ada dalam dalam puisi Indonesia "Gugur" karya Rendra berbeda dengan puisi Arab "Bitāqah Hāwiyyah" karya Darwisy. Pandangan nasionalisme mengenai cinta terhadap tanah air memiliki perspektif bahwa negara itu adalah jiwa dan kehormatan yang harus selalu dijaga bagi penduduk Indonesia. Jiwa adalah seluruh kehidupan batin manusia. Negara Indonesia adalah milik penduduk Indonesia dan telah menyatu dengan mereka. Oleh karena itu, penduduk Indonesia akan melakukan apa saja 
untuk menjaga dan mempertahankan negara dari tangan asing, yaitu penjajah itu sendiri. Hal itu juga terlihat jelas dalam puisi itu.

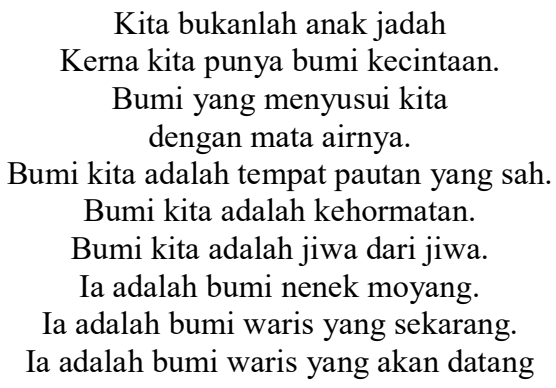

Karena negara merupakan bumi kecintaan, jiwa, dan bahkan kehormatan, maka dalam keadaan apapun para pejuang terus semangat menuju kepada kemerdekaan. Negara yang merupakan warisan leluhur harus dijaga dan dipertahankan dari ancaman asing yang bisa saja dengan mudah menguasainya. Ketika negara jatuh ke tangan penjajah, penduduk Indonesia merasa bahwa kehormatan mereka telah diinjak-injak karena negara merupakan sesuatu yang penting dan utama dan juga menjadi sumber kehidupan bagi penduduknya. Oleh karena itu, sebagai penduduk Indonesia, baik muda maupun tua harus menjunjung tinggi nilai solidaritas rasa nasionalisme untuk mengamankan keadaan negara dari berbagai ancaman.

Rasa cinta sang pejuang Indonesia terhadap negara Indonesia sudah tidak diragukan lagi. Ia menganggap bahwa bumi yang dipijaknya adalah bumi yang cintainya. Meskipun ia sudah tua dan sudah berada di ujung maut, ia masih memiliki semangat yang tinggi dalam membela tanah air. Dedikasi dan kesetiaannya kepada negara Indonesia membuatnya menjadi contoh seorang penduduk yang memiliki rasa nasionalisme yang tinggi. Hal itu membenarkan pendapat Hans Kohn yang beranggapan bahwa nasionalisme adalah suatu paham yang berpendapat bahwa kesetiaan tertinggi individu harus diserahkan kepada negara kebangsaan. Dalam puisi tersebut, terdapat pengulangan kalimat 'Ia merangkak, di atas bumi yang dicintainya' sebanyak tiga kali. Hal itu jelas bahwa bumi Indonesia adalah tanah yang penting dan sang pejuang itu memiliki keterikatan yang kuat dengan negaranya. Perjuangannya terlihat jelas pada bait kedua puisi tersebut.

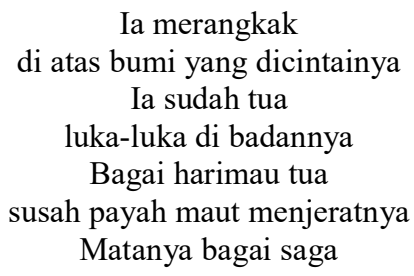




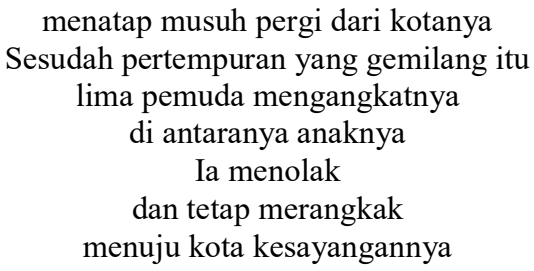

Dengan demikian, nasionalisme yang digambarkan dalam puisi Rendra menjadi suatu tema yang kuat. Selain itu, puisi tersebut juga menggambarkan bahwa negara itu adalah jiwa dari penduduknya yang tidak dapat dipisahkan dan menjadi sebuah sumber kehidupan bagi penduduknya.

\section{KESIMPULAN}

Perjuangan dan nasionalisme adalah dua hal yang tidak dapat dipisahkan. Perjuangan membela dan mempertahankan negara dari penjajahan dilakukan karena adanya kesetiaan dan rasa cinta yang besar kepada tanah air. Hal itu merupakan wujud rasa nasionalisme terhadap bangsa dan negara. Nasionalisme adalah hal penting yang seharusnya dimiliki setiap penduduk suatu bangsa. Dengan semangat nasionalisme, setiap penduduk suatu negara merasa terikat dengan negaranya dan juga merasa memiliki negara itu.

Seperti yang telah dijelaskan dalam analisis di atas, bentuk nasionalisme pada dua puisi tersebut adalah adanya rasa cinta dan setia pada negara. Namun, kedua puisi tersebut memiliki perspektif yang berbeda dalam memandang suatu negara. Dalam puisi Darwisy, negara Palestina digambarkan sebagai sebuah rumah. Palestina adalah suatu tempat berlindung bagi rakyatnya. Palestina juga merupakan tempat berpijak dan berkehidupan dengan keluarga, serta tempat dimana rakyatnya dapat bekerja untuk menghidupi keluarganya. Untuk itu, ketika ada pihak yang ingin merebut wilayah maupun kekuasaan Palestina, rakyat Palestina tidak tinggal diam. Mereka berjuang matimatian untuk mempertahankan Palestina agar tidak jatuh ke tangan penjajah.

Adapun dalam puisi Rendra, pandangan mengenai negara memiliki artian yang berbeda. Pada puisi tersebut, negara lebih dipandang sebagai jiwa yang tidak terpisahkan dari tubuh manusia. Untuk itu, jiwa harus dijaga apapun keadaannya. Hal itu menunjukkan bahwa negara merupakan hal yang tidak dipisahkan dengan penduduknya. Keduanya telah menyatu dan saling membutuhkan satu sama lain. Manusia dapat hidup karena adanya jiwa, begitupun dengan penduduk juga membutuhkan negara untuk hidup. 
Evayatun Ni'mah

\section{Daftar Pustaka}

Ahmad, Hamoud Yahya dan Ruzy Suliza Hashim. Tanpa Tahun. An Ecopostcolonial Perspective of Home in Mahmoud Darwish's Poetry. Advances in Enviroment, Computational Chemistry and Bioscience.

Darwisy, Mahmūd. 2005. Ad-Dīwānn: al-A'māl al-Ūlā 1. Beirut: Riad El-Rayyes Books.

Kahin, George Mc Turnan. 1995. Nasionalisme dan Revolusi di Indonesia, Jakarta: Sinar Harapan.

Kohn, Hans. 1985. Nasionalisme: Arti dan Sejarahnya. Jakarta : Penerbit Erlangga.

Laurenson, Diana dan Alan Swingewood. 1972. Sociology of Literature. London: Granada Publishing Limited.

Moesa, Ali Maschan. 2007. Nasionalisme Kiai. Yogyakarta: Lkis.

Newton P. Stallknect dan Horst Frenz (Ed). 1961. Comparative Literature: Method and Perspective. Carbondale: Southern Illinois University Press

Ritter, Herry. 1986. Dictionary of Concepts in History. New York: Greenwood Press.

Kartodirdjo, Sartono. 1999. Pengantar Sejarah Indonesia Baru: Sejarah Pergerakan Nasional dari Kolonialisme Sampai Nasionalisme, Jilid 2. Jakarta: Gramedia.

Rendra, W.S. 1961. Manuskrip Puisi: Empat Kumpulan Sajak. Jakarta: Direktorat Jenderal Pendidikan Dasar dan Menengah Departemen Pendidikan Nasional.

Shafer, Boyd C. 1955. Nationalism Myth and Reality. New York: A Harvest Book Harcourt.

Smith, A. D. 1979. Nationalist Movement. London: The Macmillan Press.

Snyder, L. L. 1964. The Dynamic of Nationalism. Princeton: D. Van Nostrand Co. Inc. 